\title{
KORUPSI, KOLUSI DAN NEPOTISME DALAM PERSPEKTIF HUKUM ISLAM (PROBLEM DAN SOLUSINYA)
}

\author{
Ridwan Jamal ${ }^{1}$
}

\begin{abstract}
Abstrak
Korupsi, kolusi dan nepotisme dapat menjatuhkan sebuah rezim dan bahkan menyengsarakan suatu bangsa sebab korupsi merupakan suatu penyelewengan untuk kepentingan pribadi, sedangkan kolusi merupakan suatu persekongkolan rahasia untuk maksud dan tujuan yang tidak terpuji dan npotisme merupakan suatu kecenderungan untuk mengutamakan sanak saudara sendiri dalam suatu jabatan dilingkungan pemerintahan. Korupsi, kolusi dan nepotisme yang dipahami dari segi agama Islam jelas menunjukkan bahwa hal tersebut merupakan suatu pelanggaran hukun dalam arti merugikan orang lain, melanggar hak asasi manusia. Penyebab terjadinya hal tersebut disebabkan rapunya kualitas moral.
\end{abstract}

Kata Kunci : Korupsi, Kolusi, Nepotisme, Hukum Islam.

\section{A. Pendahuluan}

Sikap manusia terhadap kejahatan berbeda-beda, tergantung dari pandangan hidupnya. Orang yang bersikap skeptis mungkin akan bertanya, kalau KKN itu tak dapat disingkirkan sama sekali, untuk apa bersusah payah berusaha menegakannya atau memberantasnya? Orang yang berpikir demikian, selain malas berpikir, lupa bahwa masalah KKN memiliki tiga sisi, di satu pihak pelaku KKN dan di pihak yang orang lain atau orang-orang yang menderita yang menjadi korban $\mathrm{KKN}$ itu, dan masyarakat pada umumnya mau tidak mau selalu tersangkut dalam setiap tindakan kejahatan tersebut dan akibatnya.

Sebagaian besar tindakan yang dianggap KKN oleh mereka yang melaksanakan norma dalam sistem politik atau oleh pengancam di luar sistem,

\footnotetext{
${ }^{1}$ Penulis adalah dosen tetap pada Jurusan Syari’ah STAIN Manado.
} 
pada dasarnya adalah variasi "transaksi pertukaran". Dilihat dari tehnik yang dipakai, "penukar transaksi” tersebut menimbulkan beraneka ragam kewajiban dengan sifatnya yang khusus. Salah satunya adalah tehnik KKN yang paling sering dikutip, karena perbuatan itu menimbulkan kewajiban paling khas di pihak pemegang jabatan. Makin banyak "transaksi” pertukaran politis. Pejabat yang disuap secara khusus setuju untuk melakukan atau membatalkan tindakan yang ditujukan sebagai imbalan atas kompensasi yang ditentukan.

Oleh karena itu, nilai suapan/sogok yang diterima akan diabaikan, tidak oleh perasaan bersalah dan tidak oleh karena takut terhadap kutukan moral. ${ }^{2}$ Diduga pemegang jabatan akan menerima suapan kalau ia tidak akan dihukum dan masyarakat yang berpengetahuan memang menyalahkan kesediaan untuk menerima suapan kepada pejabat seakan-akan karena jabatan (ex officio).

Masalah KKN telah lama sejarahnya sejalan dengan sejarah manusia itu sendiri. Demikian pula perjuangan untuk menentangnya juga tidak kurang lamanya dalam sejarah manusia itu sendiri. Namun KKN dalam bentuk, rupa dan ruang lingkupnya seperti sekarang ini, belum pernah ada dalam sejarah umat manusia sebelumnya. KKN dapat menjatuhkan sebuah rezim dan bahkan juga menyengsarakan suatu bangsa.

KKN dapat digolongkan dengan berbagai cara, salah satu tipe klasifikasi dapat memakai skala, yakni mulai dengan manipulasi besar di puncak dan turun

${ }^{2}$ Edward C. Benfield, The Moral Basic of a Backward Society, (New York: The Free Press, 1958), h. 258. 
ke bawah dalam bentuk "uang kilat" dan hadiah berupa rokok. ${ }^{3}$ Klasifikasi ini menbawa ke perbedaan kualitatif yang berguna antara KKN tingkat tinggi dan KKN tingkat rendah, keduanya dalam organisasi pemerintah yang tunggal dan meliputi berbagai tingkat sistem pemerintah, nasional, propensi, kabupaten, kecematan bahkan ke tingkat desa.

Jenis klasifikasi ke dua dapat membedakan berbagai tipe penyimpangan sumber menurut metode yang dipakai oleh pelaku. Ada pejabat yang langsung mengalihkan dana di bawah pengawasanya, dan pejabat lain memakai wewenang resminya untuk memerintahkan pembayaran tidak resmi dari pihak swasta yang berusaha memperoleh hak-hak istimewa dari pemerintah. ${ }^{4}$

Dari uraian di atas penulis membatasi pada titik permasalahan yaitu Bagaimana Korupsi, Kolusi dan Nepotisme Dalam Perspektif Hukum Islam? (Problem Dan Solusinya).

\section{B. Pengertian}

Dalam Kamus Besar Bahasa Indonesia yang ditulis oleh Tim Penyusun Kamus Pusat Pembinaan dan Pengembangan Bahasa memberikan pengertian tentang KKN, kolusi dan nepotisme sebagai berikut.

\footnotetext{
3“uang kilat" atau "uang semir" ialah sogokan kecil yang diberikan dengan asumsi bahwa izin atau tindakan pemerintah diperlukan akan dibebaskan atau dihapuskan secepat mungkin.

${ }^{4}$ Muchtar Lubis dan James C. Scott, KKN Politik (Jakarta: Yayasan Obor Indonesia, 1993), h. 49-50.
} 
1. Korupsi adalah sebagai penyelewengan atau penggelapan (uang negara/perusahaan, organisasi) untuk kepentingan pribadi. $^{5}$

2. Kolusi adalah sebagai persekongkolan rahasia untuk maksud atau tujuan yang tidak terpuji. ${ }^{6}$

3. Nepotisme diartikan sebagai kecenderungan untuk mengutamakan (menguntungkan) sanak saudara sendiri, terutama dalam jabatan, pangkat, di lingkungan pemerintah, atau tindakan memilih kerabat atau sanak saudara sendiri untuk memegang pemerintahan. ${ }^{7}$

4. Perspektif berarti pandangan luas, peninjauan dan tinjauan. ${ }^{8}$

5. Hukum Islam meliputi semua hukum Islam yang telah disusun dengan terartur oleh para ahli fiqh dalam pendapat fiqhnya mengenai persoalan di masa mereka, atau mereka perkirakan ${ }^{9}$ akan terjadi kemudian. Dengan mengambil dalil-dalilnya langsung dari alquran dan hadis atau sumber pengambilan hukum seperti ijma', qiyas, istihsan, istishab dan marsalah mursal.

Dalam literatur keislaman istilah $\mathrm{KKN}$ identik dengan risywah, kolusi searti dengan taamur atau tawathu (dalam istilah alquran termasuk ta'awun 'ala al-itsm wa al-'udwan) dan nepotisme dengan atsarat al-aqarab. Ketiga istilah ini

\footnotetext{
5 Tim Penyusun Kamus Pusat Pembinaan dan Pengembangan Bahasa, Kamus Besar Bahasa Indonesia, (Jakarta: Balai Pustaka, 1988), h. 527.

${ }^{6}$ Ibid.

${ }^{7}$ Ibid.

${ }^{8}$ W.J.S Poerwadarminto, Kamus Umum Bahasa Indonesia, (Jakarta: Balai Pustaka, 1982), h. 1078. lihat pula Pius A Partanto, dkk, Kamus Ilmiah Populer, (Surabaya: Arkola, 1994), h. 592.

${ }^{9}$ Ahmad Zaki Yamani, Asy-Syari'atul Khalidah wal Musykilatul 'Asr, diterj. Oleh K. M. Agustik, Syari'at Islam yang Kekal dan Persoalan Masa Kini, (Jakarta: Lembaga Studi Ilmu Kemasyarakatan, 1978), h. 14.
} 
(KKN) pada umumnya berakar dari kecenderungan pribadi (baca: hawa nafsu) yang tidak dapat dikendalikan oleh seseorang, sehingga dapat melahirkan tindakan tidak resmi "untuk tidak mengatakan terpuji" melanggar hukum yang ada. Sebagai konsekwensi logisnya dapat bermuara pada tindakan yang merugikan orang lain, merugikan kepetingan bersama dan sekaligus merugikan lembaga atau institusi.

Namun demikian jika ditilik secara detail ketiga istilah korupsi, kolusi dan nepotisme dalam tataran defenitif masih dapat dinedakan satu sama lain. Yang disebutkan pertama lebih berkonotasi penyalahgunaan kepentingan umum (mashalih 'ammah) termasuk di dalamnya negara, pemerintah, masyarakat atau organisasi/perusahaan) untuk kepentingan pribadi atau golongan. Yang disebut kedua adalah cenderung berkonotasi penyalahgunaan kedudukan, wewenang dan jabatan untuk mewujudkan maksud dan kepentingan sekelompok orang yang berkepentingan sama. Sedangkan disebut terakhir adalah berkonotasi pada pengutamaan kerabat dekat dalam pengangkatan suatu kedudukan dan jabatan dalam pemerintahan atau perusahaan.

\section{Pembahasan}

KKN dalam prakteknya memiliki ragam makna. Sejumlah pakar dari berbagai disiplin ilmu bersilang pendapat untuk merumuskam pengertian tersebut. Seorang pejabat dikatakan KKN apabila ia menerima hadiah dari seseorang agar ia mengambil keputusan yang menguntungkan kepentingan sang pemberi hadiah. 
Istilah ini kadang juga dikenakan pada pejabat yang menggunakan uang negara yang berada di bawah pengawasannya untuk kepentingan pribadi.

KKN sebagai tingkah laku pejabat yang menyipang dari norma yang telah diterima oleh masyarakat dengan maksud untuk mencapai tujuan pribadi. Bentuk lainnya adalah balas jasa dari pihak ketiga yang diterima atau diminta oleh seorang pejabat. Dari ilustrasi di atas, ciri yang sangat menonjol dalam KKN adalah tingkah laku pejabat yang melanggar asas pemisahan keuangan pribadi dengan keuangan milik masyarakat.

KKN juga terjadi pada tindakan di luar hukum untuk mempegaruhi tindakan dan kebijakan borokrasi. Di sini KKN ditujukan untuk "membeli" persetujuan pejabat yang bertanggung jawab dalam menetapkan dan melaksanakan kebijakan tertentu.

Oleh karena itu, Semuel P. Huntington dalam bukunya Political Order in Changing Societies, menyatakan bahwa dari segi tipologi korupsi dapat dibagi dalam tujuh jenis yaitu:

1. Korupsi transaksional (Tansactive Corruption), yaitu korupsi yang melibatkan dua pihak. Keduanya sama-sama mendapat keuntungan dan karenanya sama-sama mengupayakan secara katif terjadinya korupsi.

2. Korupsi yang bersifat memeras (Etortive Corruption), yaitu apabila pihak pertama harus melakukan penyuapan terhadap pihak kedua guna menghindari hambatan usaha dari pihak kedua itu. 
3. Korupsi yang bersifat ontogenik (Autogenic Corruption), yaitu hanya melibatkan orang yang bersangkutan. Misalnya seorang anggota perlemen mendukung golnya sebuah rancangan undang-undang, semata kerena undang-undang tersebut akan membawa keuntungan baginya.

4. Korupsi defensif (Defensive Corruption), yaitu ketika seseorang menawarkan uang suap untuk membela dirinya.

5. Korupsi yang bersifat investasi (Invenstif Corruption), misalnya memberikan palayanan barang atau jasa dengan sebaik-baiknya agar nanti mendapat uang ‘terima kasih' atas pelayan yang baik tersebut.

6. Korupsi yang bersifat nepotisme (Nepotistic Corruption), yaitu menunjukkan 'orang-orang saya' untuk jabatan-jabatan umum kemasyarakatamn, atau bahwa 'keluarga' sendiri mendapat perlakuan khusus dalam banyak hal.

7. Korupsi suportif (Supportive Corruption), yaitu korupsi yang tidak secara langsung melibatkan jasa, uang, atau pemberian apapun. Misalnya, membiarkan berjalannya sebuah tindakan korupsi dan bersikap masa bodoh terhadap lingkungan dan situasi yang korup. ${ }^{10}$

Husaein Alatas menyatakan dalam bukunya bahwa terdapat ciri-ciri dari korupsi yaitu:

1. Suatu pengkhianatan terhadap kepercayaan;

\footnotetext{
${ }^{10}$ Semuel P. Huntington, Political Order in Changing Societies, (New Haven: Yale University Press, 1977), h. 37-39.
} 
2. Penipuan terhadap badan pemerintah, lembaga swasta atau masyarakat umum;

3. Dengan sengaja melalaikan kepentingan umum untuk kepentingan khusus;

4. Dilakukan dengan rahasia, kecuali dalam keadaan di mana orang-orang yang berkuasa atau bahwasanya menganggapnya tidak perlu;

5. Melibatkan lebih dari satu orang atau pihak;

6. Adanya kewajiban dan keuntungan bersama, dalam bentuk kenyataan yang lain;

7. Terpusatnya kegiatan (KKN) pada mereka yang menghendaki keputusan yang pasti dan mereka yang dapat mempengaruhinya;

8. Adanya usaha untu menutupi perbuatan kurop dalam bentuk-bentuk pengesahan hokum;

9. Menunjukkan fungsi ganda yang kontradiktif pada mereka yang melakukan korupsi. ${ }^{11}$

Sementara itu Dawan Rahardjo melihat bahwa KKN merupakan gejala dan fenomena amat mutakhir yang muncul di akhir orde baru ini, sebagai bentuk baru dari KKN yang dikenal dalam masyarakat. Dengan ciri-ciri yaitu:

1. Peranan pemerintah yang sangat kuat dalam pembangunan ekonomi maupun dalam mendorong perkembangan bisnis;

2. Tumbuhnya korupsi dan konglomerasi yang perkembangan dan besarnya sangat mengesankan;

\footnotetext{
${ }^{11}$ Husaein Alatas, The Sociology of Corruption, (Singapore, Times Indonesia, 1993), h. 49-50.
} 
3. Sedikit orang yang mendapatkan kesempatan dan mampu megembangkan usaha yang berat;

4. Nampaknya kerja sama antara pengusaha-pengusaha tertentu dengan penguasa;

5. Berkembangnya politik sebagai sumber daya baru atau faktor produksi baru yang menentukan harga yang tinggi atau kenaikan harga dan pembagian wilayah pasar. $^{12}$

Dalam analisis fenomenologis, menurut Alatas, KKN mengandung dua unsur penting, yaitu penipuan dan pencurian. Apabila bentuknya pemerasan, itu berarti pencurian melalui pemaksaan terhadap korban. Apabila berbentuk penyuapan terhadap pejabat, itu berarti membantu terjadinya pencurian. Jika terjadi dalam penentuan kontrak, korupsi ini berarti pencurian keputusan sekaligus pencurian uang hasil keputusan itu. ${ }^{13}$

Dari analisas tersebut di atas Lubis mencoba mengindentifikasikan beberapa variable yang mempengaruhi perebakan KKN, khususnya di Indonesia yaitu:

1. Penjajahan telah turut andil mengembangkan budaya korupsi di Indonesia. Penjajahan telah melahirkan berbagai kebijakan yang kondusif bagi praktik korupsi, misalnya, gaji pegawai yang amat rendah.

\footnotetext{
${ }^{12}$ Dawan Rahardjo, "Korupsi, Kolusi dan Nepotisme Kajian Konseptual dan Sosiokultural”, dalam “ Menyingkap Korupsi, Kolusi dan Nepotisme di Indonesia, (Yogyakarta: Aditya Media, 1998), h. 27.

${ }^{13}$ SH. Alatas , Korupsi: Sifat, Sebab, dan Fungsi, (Jakarta LP3ES, 1987), h. 129.
} 
2. Variabel kebudayaan, misalnya, budaya siri (malu) untuk melakukan penipuan, pencurian dan lali-lainnya.

3. Variabel ekonomi. Rendahnya gaji pegawai negeri serta tingginya kebutuhan sehari-hari untuk menutupi kebutuhan sandan dan pangan.

4. Variabel struktur. Struktur kekuasaan yang desentralistik, yang mengakibatkan terbatasnya pengambilan keputusan dan melimpahnya para "pengharap" keputusan, situasi ini membuatnya rakus dan gampang memeras

5. Variabel partai politik. Sumber dana parpol di negara berkembang sangat tidak mapan, sebab itu parpol berharap banyak pada bantuan negara.

6. Veriabel kemiskinan. ${ }^{14}$

Menurut penulis sedikit berseberangan dengan pendapat di atas, penulis melihat bahwa justru yang paling banyak melakukan penyelewengan adalah para pejabat yang note benenya tidak miskin, bahkan justeru kaya. Kehidupannya jauh dari cukup untuk tidak dinyatakan miskin. Ada satu hal yang menurut penulis yang terlupakan bagi pejabat ketika ia menduduki jabatan kekuasaan bahwa itu adalah titipan sementara pada suatu saat akan pergi (pensiun) atau akan ditinggalkan (wafat), karena itu jabatan itu merupakan amanat yang harus dijalankan secara baik dan jujur.

Karena itu, agama, khususnya agama Islam yang dibawa oleh Nabi Muhammad Saw., dating tidak hanya membawa akidah keagamaan atau ketentuan

\footnotetext{
${ }^{14}$ Mochtar Lubis dan James C. Scott, Korupsi Politik, (Jakarta: Yayasan Obor Indonesia, 1993), h. 51-54.
} 
moral dan etika yang hanya menjadi dasar masyarakat semata-mata. Akan tetapi, Islam juga membawa syari'at yang jelas mengatur manusia, perilakunya dan hubungan antara satu sama lainnya dalam segala aspek, baik bersifat individu, keluarga, hubungan individu dengan masyarakat maupun hubungan-hubungan yang lebih luas. ${ }^{15}$

Alquran yang melibatkan seluruh kehidupan moral, keagamaan dan sosial, tidak berisi teori-teori dalam arti yang baku, sekalipun ia membentuk keseluruhan etos Islam. Jadi bagaimanakah cara mengeluarkan etos ini menjadi sangat penting dalam studi etika Islam. ${ }^{16}$

Sifat dasar etika adalah kritis. Etika bertugas mempersoalkan normanorma yang dianggap berlaku. Diselidikinya apakah dasar itu membenarkan ketaatan mengaiukan pertanyaan yang melegitimasinya. Etika juga mempersoalkan tentang hak dari setiap lembaga, keluarga atau pemerintahan, bahkan agama. Dengan demikian, etika dapat mengantar orang pada kemampuan untuk bersikap kritis dan rasional, untuk membentuk pendapat dan bertindak sesuai dengan apa yang dipertanggungjawabkan.

Etika kepemimpinan Islam terwujud dalam bentuk tegaknya amanat, ketaatan, dan musyawarah. Pengkhianatan atas amanat masyarakat adalah perbuatan terlarang dan bernilai dosa. Seperti yang ditegaskan oleh Allah Swt., dalam QS. al-Anfal: 27

\footnotetext{
${ }^{15}$ Muhibbin, Islamic Political Thaught, diterjemahkan oleh, Muntaha Azhari, HadisHadis Politik, (Yogyakarta: Pustaka Pelajar, 1997), h. 27.

${ }^{16}$ Madjid Fakhry, Ethical Theories In Islam dietrjemahkan oleh Zakiyuddin Baidhawy, Etika dalam Islam, (Jakarta: Pustaka Pelajar, 1997), h. XV.
} 


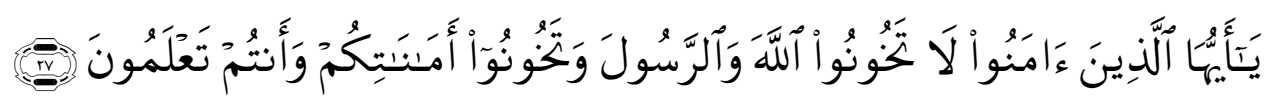

Artinya :

"Hai orang-orang yang beriman janganlah kamu mengkhianati Allah dan Rasul-Nya dan janganlah kamu mengkhianati amanat-amanat yang dipercayakan kepadamu, sedang kamu mengetahui." ${ }^{27}$

Kemudian perbuatan curang dan penipuan yang secara langsung merugikan keuangan negara. Allah memperingatkan agar kecurangan dan penipuan itu dihindari sebagaiman firman-Nya. Dalam QS. Ali Imran: 161 yang berbunyi:

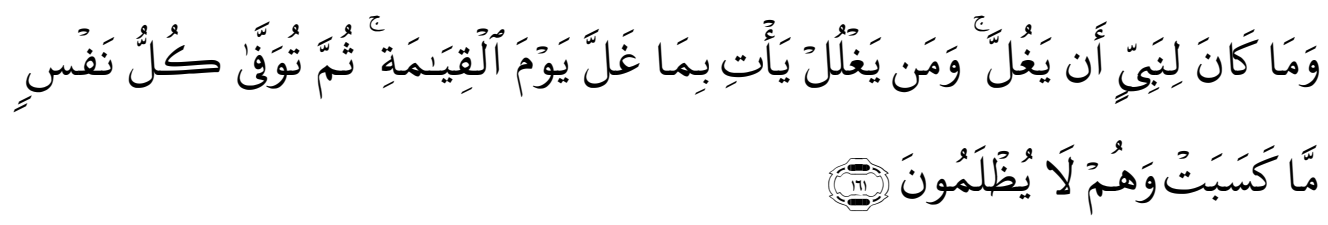

Artinya :

"Tidak mungkin seorang nabi berkhianat dalam urusan rampasan perang itu, maka pada hari kiamat ia akan datang dengan membawa apa yang dikhianatkannya itu". ${ }^{18}$

Hal ini juga dijelaskan dal alquran dalam QS. an-Nisa'/4:29

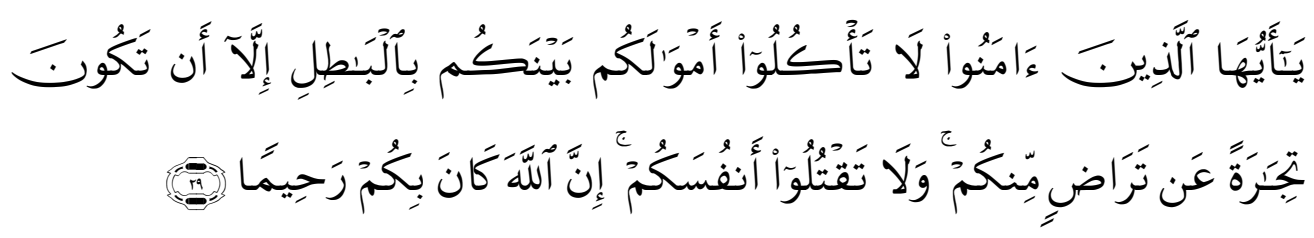

Artinya

${ }^{17}$ Departemen Agama RI, op. cit., h. 264.
${ }^{18}$ Departemen Agama RI, op. cit., h. 104 
"Hai orang-orang yang beriman, janganlah kamu saling memakan harta sesamamu dengan jalan batil/tidak sah dan tidak etis, kecuali dengan jalan perniagaan yang berlaku dengan suka sama suka di antara kamu". ${ }^{19}$

Dari ayat di atas tersebut penulis berkesimpulan bahwa larangan korupsi, kolusi dan nepotisme sebagaimana yang dipahami dari ajaran agama tersebut jelas menunjukkan bahwa hal tersebut melanggar hukum, berlaku aniaya (tidak bermoral) dalam arti merugikan pihak lain, dan melanggar hak-hak asasi manusia (tidak ada kebebasan dan keterbukaan dalam bermua'malah). Maraknya korupsi di Indonesia, menurut penulis disebabkan rapunya kualitas moral.

Terdapat tujuh butir yang perlu untuk memberantas korupsi:

1. Kemauan politik (political will) yang kuat pemerintah harus terlebih dahulu menyatakan tekad kuat untuk memberantas korupsi sampai ke akarnya.

2. Hukum yang tajam. Perangkat hukum yang ada di Indonesia relatif memadai. Hanya saja tampaknya perlu pematangan dan peninjauan ulang terhadap sejumlah aturan yang kurang relevan.

3. Pencatatan kekayaan pejabat sebelum dan sesudah menjabat

4. Dorongan kuat dari masyarakat dalam memberantas korupsi. Untuk memperkuat kontrol masytarakat diperlukan sebuah pers yang bebas. Pers bebas akan membeberkan secara terbuka setiap kasus korupsi. Dengan

\footnotetext{
122.

${ }^{19}$ Departemen Agama RI, Alquran dan Terjemahnya, (Surabaya: Jaya Sakti, 1989), h.
} 
begitu, pers dapat menjadi pressure power untuk menekan sikap tegas dari aparat.

5. Aparat khusus dalam suatu badan ekstra-struktural. Pembentukan badan independen untuk memberantas KKN.

6. Aparat penegak hukum yang tegas dan lugas. Untuk mewujudkan butir ini diperlukan integritas yang tinggi.

7. Sistem pengawasan dalam negara yang betul-betul mantap. ${ }^{20}$

Dalam "Action against corruption" tardapat tawaran untuk mencari solusi atas masalah KKN, aksi dan strategi itu dapat disebutkan:

1. Loyalitas utama dari pejabat public harus pada kepentingan umum, bukan dari persorangan, parti politik, ataupun departemen tertentu.

2. Pejabat publik jangan menggunakan kewenangan untuk kepentingan pribadi dan keluarganya.

3. Pejabat publik jangan menggunakan kekayaan publik, jasa, dan informasi, untuk aktivitas di luar tugas resminya.

4. Harus ada keterbukaan kekayaan/asset.

5. Pejabat publik harus menolak setiap pemberian yang akan mempengaruhi fungsi, tugas, dan keputusannya.

6. Kegiatan politik dari pejabat publik jangan merusak/mengganggu kepercayaan masyarakat terhadap sikap netral/tidak berpihak dari pejabat itu dalam melakukan fungsi/tugasnya. ${ }^{21}$

\footnotetext{
${ }^{20}$ Munawar Fuad Noeh, Islam dan Gerakan Moral Antikorupsi, (Jakarta: Zikru'l-Hakim, 1997), h. 137-140.
} 


\section{Kesimpulan}

Program pemerintah untuk menanggulangi atau melenyapkan KKN tergantung pada keadaan dan kemauan kelompok pemimpin. Penyusunan program tergantung pada kesadaran mereka yang terlibat; pengertian dan pemahaman mereka akan sifat, sebab-sebab dan akibat KKN. Begitu suatu pemerintahan menetapkan untuk memberantas KKN dan mempunyai kesempatan untuk itu, tidaklah sulit untuk mengubah situasi, secara bertahap tetapi mantap. Perencanaan harus benar-benar sehat. Sekedar publisitas tidaklah cukup, hal yang dibutuhkan ialah membuang pejabat yang ber-KKN secara sistematis dan berlanjut, pembaharuan administrasi, sehingga tidak mungkin pusat-pusat $\mathrm{KKN}$ terbentuk dan menjalakan kebijaksanaan ekonomi yang memungkinkan orang mencapai taraf hidup yang layak.

Dari uraian yang dipaparkan, penulis mengambil kesimpulan bahwa terdapat tiga komponen dalam memberantas KKN yaitu:

1. Menetapkan sebuah sistem evaluasi kinerja yang baru.

2. Mengumpulkan informasi tentang korupsi.

3. Menghukum dengan segera pejat yang korup.

\footnotetext{
${ }^{21}$ Ibid., 136.
} 


\section{Daftar Pustaka}

Alatas, Husaein, Korupsi: Sifat, Sebab, dan Fungsi, Jakarta: LP3ES, 1987. , The Sociology of Corruption: Singapore: Times Indonesia,1993.

Benfield, Edward C,. The Moral Basic of a Backward Society, New York:: The Free Press, 1958.

Huntington, Semuel P. Political Order in Changing Societies, New Haven: Yale University Press, 1977.

Poerwadarminto, W.J.S, Kamus Umum Bahasa Indonesia, (Jakarta: Balai Pustaka, 1982), h. 1078. lihat pula Pius A Partanto, dkk, Kamus Ilmiah Populer, Surabaya: Arkola, 1994.

Rahardjo, Dawan, "Korupsi, Kolusi dan Nepotisme Kajian Konseptual dan Sosiokultural", dalam "Menyingkap Korupsi, Kolusi dan Nepotisme di Indonesia, Yogyakarta: Aditya Media, 1998.

Lubis, Mochtar dan Scott, James C, Korupsi Politik, Jakarta: Yayasan Obor Indonesia, 1993.

Muhibbin, Islamic Political Thaught, diterjemahkan oleh, Muntaha Azhari, Hadis-Hadis Politik, Yogyakarta: Pustaka Pelajar, 1997.

Fakhry, Madjid, Ethical Theories In Islam diterjemahkan oleh Zakiyuddin Baidhawy, Etika dalam Islam, Jakarta: Pustaka Pelajar, 1997.

Noeh, Munawar Fuad, Islam dan Gerakan Moral Antikorupsi, Jakarta: Zikru'lHakim, 1997.

Tim Penyusun Kamus Pusat Pembinaan dan Pengembangan Bahasa, Kamus Besar Bahasa Indonesia, Jakarta: Balai Pustaka, 1988.

Yamani, Ahmad Zaki, Asy-Syari'atul Khalidah wal Musykilatul 'Asr, diterj. Oleh K. M. Agustik, Syari'at Islam Yang Kekal dan Persoalan Masa Kini, Jakarta: Lembaga Studi Ilmu Kemasyarakatan, 1978. 